\title{
Chapter 6 \\ How Human Rights Cross-Pollinate and Take Root: Local Governments and Refugees in Turkey
}

\author{
Elif Durmuş
}

\section{Contents}

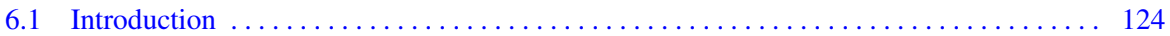

6.2 Syrian Refugees, Local Governments, and Legal Ambiguity ….............. 127

6.3 The Effectiveness of Human Rights: From Formalist to Sociological Perspectives . . . . 129

6.4 Grounded Theory Approach and Methodology ...................... 133

6.5 Factors Facilitating the Cross-Pollination and Taking Root of Human Rights as a Norm in Local Governance ........................................... 135

6.5.1 Institutional Capacity in Local Governments . ..................... 135

6.5.2 Networks and the Dissemination of the Developing Norm that Local

Governments Can/Should Improve Refugee Rights ............... 144

6.5.3 Coordination and Cooperation Between Local Governments and Other

Actors ........................................... 147

6.5 .4 Political Will .......................................... 149

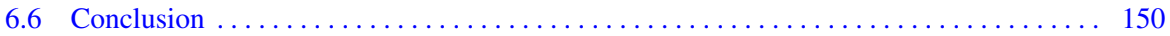

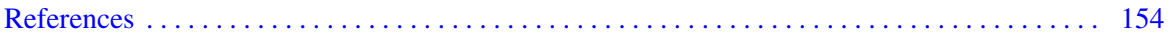

Abstract The human rights regime-as law, institutions and practice-has been facing criticism for decades regarding its effectiveness, particularly in terms of unsatisfactory overall implementation and the failure to protect the most vulnerable who do not enjoy the protection of their States: refugees. Turkey is the country hosting the largest refugee population, with around four million at the end of May 2020 (https://www.unhcr.org/tr/wp-content/uploads/sites/14/2020/06/UNHCR-Tur key-Operational-Update-May-2020.pdf). As an administratively centralised country, Turkey's migration policy is implemented by central government agencies, but this has not proved sufficient to guarantee the human rights of refugees on the ground. Meanwhile, in connection with urbanisation, decentralisation and globalisation, local governments around the world are receiving increasing attention from migration studies, political science, law, sociology and anthropology. In human rights scholarship, the localisation of human rights and the potential role of local governments have been presented as ways to counter the shortcomings in the effectiveness of the human rights regime and discourse. While local governments may have much

\footnotetext{
E. Durmuş $(\bowtie)$

Faculty of Law, Economics and Governance, Cities of Refuge Research, Utrecht University, Utrecht, The Netherlands

e-mail: e.durmus@uu.nl
} 
untapped potential, a thorough analysis of the inequalities between local governments in terms of access to resources and opportunities is essential. The Turkish local governments which form the basis of this research, operate in a context of legal ambiguity concerning their competences and obligations in the area of migration. They also have to deal with large differences when it comes to resources and workload. In practice, therefore, there is extreme divergence amongst municipalities in the extent to which they engage with refugee policies. This chapter seeks to answer the question why and how certain local governments in Turkey come to proactively engage in policy-making that improves the realisation of refugees' rights. Exploratory grounded field research among Turkish local governments reveals four main factors that enable and facilitate the engagement of local governments in refugee policies: (1) the capacity of and institutionalisation in local governments; (2) the dissemination of practices and norms surrounding good local migration and rights-based governance through networks; (3) the availability of cooperation and coordination with other actors in the field, and (4) political will. Collectively, these factors illustrate how a new norm - the norm that local governments can and ought to engage in policy-making improving the rights of refugees-is cross-pollinating and taking root among Turkish local governments. This understanding will provide valuable insights into how norms are developed, travel and are institutionalised within social and institutional networks, and how differences in access, capacity, political and cooperative opportunities may facilitate and obscure the path to policies improving human rights on the ground.

Keywords Human rights • Local governments • Turkey • Institutional capacity • Local migration policies · Dissemination

\subsection{Introduction}

The gap between legal standards applicable to the protection of refugees in Turkey and the on the ground rights fulfilment mirrors two shortcomings that human rights have been facing regarding their effectiveness, since their codification in international law. The first of such shortcomings, the so-called 'enforcement gap' relates to the discrepancy between the requirements of human rights regulations and the situation on the ground. ${ }^{1}$ The second shortcoming concerns the effectiveness of human rights when it comes to protecting the most vulnerable who do not enjoy the protection of their States, sometimes referred to as the 'citizenship gap'. ${ }^{2}$ Turkey hosts the highest number of refugees worldwide — around four million people — of which

\footnotetext{
${ }^{1}$ Kennedy 2002; Hafner-Burton and Tsutsui 2005; Donoho 2007; Hopgood 2013; Posner 2014.

${ }^{2}$ Kennedy 2002; Brysk and Shafir 2004.
} 
around 3.6 million are Syrian refugees under the domestic legal regime of 'temporary protection'. ${ }^{3}$ Legislation on temporary protection is operationalised in a highly centralised manner, and there is no national long-term policy for those under 'temporary protection', nor any official integration policy. ${ }^{4}$ There is no dispersal system that allocates refugees to provinces and municipalities, no public housing scheme, and no language courses offered by the State. The central government has established regulations for the basic protection of the human rights of Syrian refugees, such as access to free health care, wide-scale schooling of children, and opportunities to work in regularised manner with work permits. ${ }^{5}$ However, the reality on the ground is that an overwhelming majority of the working refugee population are working irregularly, that the percentage of children attending school is only $50 \%$, and that access to basic rights remains problematic. ${ }^{6}$ Most refugees (98.2\%) do not live in government-run refugee camps, but in urban settlements. ${ }^{7}$ However, local governments in Turkey have no official competences in providing services to refugees under temporary protection. ${ }^{8}$ The Law on Municipalities contains contradictory clauses on whether or not local governments are obliged or even permitted to include non-citizens in their service provision, creating an atmosphere of legal ambiguity. ${ }^{9}$ Despite this lack of law's coercive force, many local governments in Turkey have opted to engage extensively in policies and practices that improve the human rights of refugees on the ground, but which also require time, energy, personnel and resources. ${ }^{10}$ Why and how is this happening?

This chapter will address the question: Why and how do certain local governments in Turkey come to engage proactively in policy-making that improves the realisation of refugees' rights? This empirical question also corresponds to a niche in literature. In response to the enforcement gap and criticism towards a legalistic understanding of how to close it, socio-legal scholars have been drawing attention to the localisation of human rights - the cultivation of locally sensitive understandings of human rights and increasing ownership — as a solution. ${ }^{11}$ At the same time, migration scholars have been discussing a 'local turn' in migration governance, with a focus on

\footnotetext{
${ }^{3}$ UNHCR Turkey: https://www.unhcr.org/tr/wp-content/uploads/sites/14/2020/06/UNHCR-Tur key-Operational-Update-May-2020.pdf. Latest 2020 numbers from the website of the Directorate General of Migration Management: https://www.goc.gov.tr/gecici-koruma5638.

${ }^{4}$ Temporary Protection Regulation, adopted by Council of Ministers Decision No: 2014/6883, 22/10/2014 No: 29153, pursuant to Law No 6458. The only long-term solutions foreseen for Syrians under temporary protection are voluntary returns and departures to third countries.

${ }^{5}$ Kayaoğlu and Erdoğan 2019.

${ }^{6}$ Erdoğan 2017; Korkmaz 2017.

${ }^{7}$ Erdoğan 2017, p. 42.

${ }^{8}$ See Sect. 6.2 for a detailed analysis. Erdoğan 2017.

${ }^{9}$ Ibid., p. 40.

${ }^{10}$ Erdoğan 2017; Adıgüzel and Tekgöz 2019; Durmuş 2020.

${ }^{11}$ Merry 2006; De Feyter et al. 2011; Goodhart 2013; Oomen and Baumgärtel 2018; Oomen and Durmuş 2019; Hoffman 2019.
} 
local authorities. ${ }^{12}$ In both research areas, local governments in non-Western countries, in centralised settings, are underexplored. Common research cases include cities such as Barcelona, Milan, Utrecht, all of which operate in a context of (increasing) decentralisation. ${ }^{13}$ Research in the Turkish context complements and furthers such research. First, as Turkish municipalities generally host far larger numbers of refugees than Western municipalities; this research will demonstrate the pitfalls of decentralisation and localisation when a comparatively lower capacity and higher burden are coupled. Second, non-involvement in human rights and migration policy-making is a common and acceptable approach in the Turkish context of legal ambiguity, political uncertainty and centralised governance. ${ }^{14}$ Researching why those municipalities that engage, do indeed engage, and how that has come to be, is therefore expected to provide important insights. Using grounded empirical insights from field research, this chapter argues that four factors enable/facilitate the engagement of local Turkish governments with policies that improve the rights of refugees: their capacity, the dissemination of norms on human rights and their role therein, the availability of cooperation, and political will. Collectively, these factors illustrate how the notion that Turkish local governments ought to contribute to the realisation of the rights of refugees is becoming a norm, is cross-pollinating and is taking root amongst Turkish local governments. These findings are derived from the Turkish context but may also shed light on structural and cultural factors that underlie the 'normativisation' and socialisation of human rights elsewhere.

On the path to these findings, Sect. 6.2 of this chapter will provide a brief legal overview of temporary protection, local governments and ambiguity. Section 6.3 will then explore the question of human rights effectiveness, in its formalist and sociological evaluations, and how local governments and this study relate to them. After describing the methodology and grounded theory approach, the four main factors that have been found to determine whether a local government will engage in policymaking for refugees will be presented and discussed: (1) its capacity and level of institutionalisation, (2) whether the ideas and practices of refugee-welcoming or human rights-friendly municipalities have reached them through networks or other means of dissemination, (3) the available coordination and cooperation with other complementary actors in the multi-level governance of migration, and (4) the presence of political will. Finally, a number of concluding remarks will address the contribution of these factors and their collective illustration of a norm's cross-pollination and taking root, to existing literature.

\footnotetext{
${ }^{12}$ Caponio and Borkert 2010; Zapata-Barrero et al. 2017; Bendel et al. 2019; Caponio et al. 2019.

${ }^{13}$ Sassen 2001; Oomen et al. 2016; Oomen and Baumgärtel 2018.

${ }^{14}$ Erdoğan 2017, p. 40.
} 


\subsection{Syrian Refugees, Local Governments, and Legal Ambiguity}

Having ratified the 1951 Geneva Convention on the Status of Refugees with a geographical reservation, Turkey does not grant asylum to people fleeing to the country from outside of Europe asylum in the country. ${ }^{15}$ In this chapter, however, Syrians under temporary protection are be referred to as refugees, as international law dictates a declaratory rather than a constitutive character to the determination of the refugee status. ${ }^{16}$ The regime provided by the Turkish Law on Foreigners and International Protection ('YUKK') $)^{17}$ for situations in which 'immediate' ${ }^{18}$ protection is needed by mass entries into the country (rendering individual assessment impossible), is the 'temporary protection' regime. ${ }^{19}$ This regime is not considered as international protection and does not offer any durable solution. ${ }^{20}$ In October 2013, the Council of Ministers adopted the Regulation on Temporary Protection in accordance with this law, declaring that all persons entering Turkey from the Syrian Arab Republic as of 25 April 2011 will be granted temporary protection. ${ }^{21}$ This would be operationalised by the national Directorate General of Migration Management ('DGMM'), in accordance with the 'Temporary Protection Regulation' enacted by the Council. ${ }^{22}$ Here, the conditions of reception centres are regulated in detail, while the only long term solutions referred are voluntary return and resettlement in a third country. ${ }^{23}$ As such, 'harmonisation', the preferred term for integration in Turkey, is not the goal of temporary protection. ${ }^{24}$ However, today $98.2 \%$ of Syrian refugees live in urban areas (rather than in reception centres in border regions), trying to survive economically and socially in densely populated metropolitan areas. ${ }^{25}$ Despite this, local governments do not appear in the Regulation, and only minimally in the YUKK, among a list of actors that the DGMM may consult when drawing up harmonisation policies. ${ }^{26}$ Local governments are thus not assigned any duties in the reception and

\footnotetext{
${ }^{15}$ Ibid., Article 61.

${ }^{16}$ Hathaway and Foster 2014.

${ }^{17}$ Law No. 6458, 'Law on Foreigners and International Protection' ('YUKK'), entered into force 11 April 2013, Unofficial English translation by the Department of Communication for Foreigners, Directorate General of Migration Management, Ministry of Interior Affairs, Turkey. https://yimer. gov.tr/EN/Legis/215f1c4c-5384-47f9-9ac2-dc2575b4d48f.

${ }^{18}$ Ibid., Article 91.

${ }^{19}$ Ibid.

${ }^{20}$ Article 7(3): 'Persons benefiting from temporary protection shall not be deemed as having been directly acquired one of the international protection statuses as defined in the Law.' Regulation, supra note 5, Article 91.

${ }^{21}$ Ibid., Provisional Article I.

${ }^{22}$ Ibid.

${ }^{23}$ Ibid., Part 9, Articles 42-45.

${ }^{24}$ YUKK, supra note 18, Article 96.

${ }^{25}$ DGMM Website: https://www.goc.gov.tr/gecici-koruma5638.

${ }^{26}$ YUKK, supra note 18, Article 96.
} 
integration of Syrian refugees. ${ }^{27}$ Nonetheless, as Syrians constitute the largest group of migrants in Turkey, most of the local government practices on migration revolve around them, and so they will be the main focus of this chapter.

The final domestic legal source to consult on the relationship between local governments and refugees, the Law on Municipalities, ${ }^{28}$ is inconsistent on the question of the beneficiaries of local services. On the one hand, Article 13 holds that anyone who resides in the territory of a local government is that locality's 'hemsehri' (fellow citizens/townspeople) and is therefore 'entitled to participate in local government's decisions and services, to be informed about local government activities and benefit from the material aid of the local government. ${ }^{29}$ The local government is then entrusted with "conduct[ing] activities as are necessary for the development of social and cultural relationships between fellow citizens and for the protection of cultural values ${ }^{\prime 30}$ and with 'ensuring the participation of universities, professional associations with public organ status, unions, civil society organisations and experts ${ }^{31}$ in these activities. This is the legal basis for all local government activities which benefit all migrants, including refugees and undocumented migrants. ${ }^{32}$

On the other hand, Article 14, titled 'Functions of Local Governments' lists all the services that local governments may or should provide, stating that these should be provided to 'nationals' (vatandaslar). This then creates legal ambiguity for local governments as to whether or not they are now obliged to, or even permitted to provide these services to non-nationals. ${ }^{33}$ The fact that local governments receive their share of the central budget according to the number of nationals residing in their territory further complicates this matter. ${ }^{34}$ As such, in extreme cases, such as Kilis, a local government could be serving a refugee population that is as large as the number of nationals registered as residents of the municipality, yet only receive a budget based on the Turkish population. ${ }^{35}$ The expenditure of local governments in Turkey, as in all public organs, is scrutinised by the Saylştay (the Court of Cassation). Interviews and conversations at local government conferences revealed that some local governments, especially those run by opposition parties, held concerns about being held accountable for spending towards non-nationals by the Sayıştay, perhaps disproportionately so in the case of opposition-governed municipalities. ${ }^{36}$ One large district municipality governed by the CHP in a metropole, stated that Sayıștay examinations

\footnotetext{
${ }^{27}$ Erdoğan 2017, p. 42.

${ }^{28}$ Law No 5393, 'Law of Municipalities', entered into force through publication in the Official Gazette: 13/7/2005 under Number 25874.

${ }^{29}$ Ibid., Article 13(1).

${ }^{30}$ Ibid., Article 13(2).

${ }^{31}$ Ibid.

${ }^{32}$ Erdoğan 2017, p. 40; interviews Sultanbeyli, Maltepe, Zeytinburnu, Keçiören.

${ }^{33}$ Erdoğan 2017, p. 40.

${ }^{34}$ Ibid.

${ }^{35}$ Ibid.

${ }^{36}$ Anonymous Interviews \#1 and \#2.
} 
sometimes last 'many months and up to a whole year' in their municipality, while AKP-led municipalities receive visits from Court officials for only one day. ${ }^{37}$

This environment of legal ambiguity, among other factors, helps to explain the extreme divergence amongst Turkish local governments in terms of their engagement with refugee policies. The discretionary spaces for local governments to act in, are shaped both by laws on their competences and legal ambiguities around these laws. ${ }^{38}$ The way in which such discretionary space is used by Turkish local governments ranges from doing absolutely nothing in the area of migration to addressing the needs of refugees by mainstreaming local services, including access for refugees, ${ }^{39}$ setting up NGOs and community centres targeting refugees, ${ }^{40}$ offering language courses, ${ }^{41}$ free local healthcare, ${ }^{42}$ vocational training, ${ }^{43}$ mobilisation projects to increase schooling rates, ${ }^{44}$ free childcare, ${ }^{45}$ free anonymous STD testing, ${ }^{46}$ psychological support, ${ }^{47}$ legal support, ${ }^{48}$ disability support ${ }^{49}$ and even political participation. ${ }^{50}$

\subsection{The Effectiveness of Human Rights: From Formalist to Sociological Perspectives}

When thinking about the theme of this book, the effectiveness of human rights, it is helpful to first pose the questions: 'Effectiveness of what?' and 'Effectiveness for what' ${ }^{51}$ When we understand human rights as a sub-field of international law, Taki's definition of effectiveness as 'the efficacy (actual observance) of law as distinguished from the validity (binding force) of law ${ }^{, 52}$ provides guidance. Like other sub-fields of

\footnotetext{
${ }^{37}$ Anonymous Interview \#2.

${ }^{38}$ Oomen et al. forthcoming.

${ }^{39}$ Interview Zeytinburnu.

${ }^{40}$ Presentation on Gaziantep during International Migration and Integration Symposium, Istanbul. Interview Sultanbeyli.

${ }^{41}$ Interviews Zeytinburnu, Bağcılar, Sultanbeyli, ABB.

${ }^{42}$ Interviews Sultanbeyli and Anonymous \#1.

${ }^{43}$ Interviews Sultanbeyli, ABB, Zeytinburnu, Bağcılar.

${ }^{44}$ Interview Bağcılar.

${ }^{45}$ Interview ABB.

${ }^{46}$ Anonymous Interview \#1.

${ }^{47}$ Interview Sultanbeyli.

${ }^{48}$ Interviews Sultanbeyli, Keçiören.

${ }^{49}$ Interview Zeytinburnu.

${ }^{50}$ Anonymous Interview \#1, Presentation by Gaziantep in International Migration and Integration Symposium, March 2018, Istanbul.

${ }^{51}$ Brysk 2019.

${ }^{52}$ Taki 2013, para 1.
} 
international law, human rights suffer from the lack of a central enforcement system. ${ }^{53}$ While there are international bodies institutionalising the human rights regime, they nevertheless rely on the consent and compliance of States and other institutions. ${ }^{54}$ In addition, due to the state-centricity of international law, individuals who are not (or no longer) able to enjoy the protection of their own States, such as refugees and stateless persons, are often deprived of the effective human rights protection that nationals of States enjoy in their own country. This is referred to as the "citizenship gap' ${ }^{55}$ To increase the effectiveness of human rights as law, scholars have demanded formalist steps such as codification, ratification and the legal incorporation of human rights treaties into domestic law. ${ }^{56}$

This formalist approach has however attracted criticism for not adequately explaining norm compliance ${ }^{57}$ Both the 'enforcement gap' and the 'citizenship gap' do not materialise equally and identically in different places. The literature assessing the effectiveness of the international human rights regime has yielded conflicting results. ${ }^{58}$ If the preferred indicator of effectiveness is not a formal one, such as treaty ratification, but rather the situation on the ground, reliance on interdisciplinarity becomes almost inevitable. An answer to the question of why some (States, regions, etc.) comply more than others is found in the sociology and anthropology of law: the ownership a community develops for a norm. ${ }^{59}$ Legal incorporation constitutes a formalist, top-down approach that does not focus on cultivating ownership for human rights, especially in places where these norms are considered foreign. ${ }^{60}$ Socio-legal scholars, especially social constructivists, argue that a top-down legalist perspective will not lead to human rights ownership among diverse communities. and that, a process of contestation involving relevant stakeholders in society should take place instead. ${ }^{61}$ As such, social constructivists often inquire about the effectiveness (or rather relevance) of human rights as an idea, value, practice, and as such a social construction, rather than as law alone. ${ }^{62}$ The responses to the questions 'effectiveness of what?' and 'effectiveness for what?' then become 'the effectiveness of human rights as a societal norm' and 'the effectiveness of human rights in influencing the behaviour of actors.'

Risse and Sikkink explain that materialist answers alone fail to explain how state identities, interests and preferences develop: 'Material factors and conditions matter through cognitive and communicative processes, the "battleground of ideas" by

\footnotetext{
${ }^{53} \mathrm{Ibid}$.

${ }^{54}$ Ibid.

${ }^{55}$ Brysk and Shafir 2004.

${ }^{56}$ Hathaway 2005; Hoffman 2019.

${ }^{57}$ Helfer 2002; cf. Hathaway 2005; Simmons 2009; Fraser 2019.

${ }^{58}$ Brysk 2019, p. 2.

${ }^{59}$ Finnemore 1993; Merry 2006; Soohoo et al. 2008; Grigolo 2016; Oomen et al. 2016.

${ }^{60}$ Fraser 2019; Hoffman 2019.

${ }^{61}$ Engle 2000; Helfer 2002; Merry 2006; An-Na'im 2010; Freeman 2013; Fraser 2019; Oomen and Durmuş 2019.

${ }^{62}$ Grigolo 2017.
} 
which actors determine their identities and interests and to develop collective understandings of the situation in which they act and of the norms guiding their interactions. ${ }^{63}$ Béland and Cox demonstrate that different ideas in this 'battleground' ${ }^{64}$ of which the notion of human rights is only one, can also constitute 'coalition magnets' that actors rally around for a common cause ${ }^{65}$ Berman and the 'New' New Haven School of Law ${ }^{66}$ also observe the world as a battleground in which ideas, values and propositions of what constitutes the law are contested, with 'norm-generating communities' proposing their own versions of what law ought to look like. ${ }^{67}$ Human rights are presented as a successful example of how a normative ideal can become accepted by the dominant actors and institutions and come to constitute official law. ${ }^{68}$ Constituting official law, however, is not the end of the road for a norm. Still, this norm must be advocated, contested and negotiated to maintain its relevance, provide opportunities for the correction of errors, ${ }^{69}$ and reaffirm its ownership amongst communities. Brysk explores 'pathways of influence' such as interdependence, diffusion, legalisation, framing and shaming - through which human rights permeates the consciousness of nations and communities and gain such ownership. ${ }^{70}$ Merry analyses the 'people in the middle' who travel between the 'local' and the 'transnational', who can speak both the language of the international rights regime and the local culture, and who 'vernacularise' international human rights norms. ${ }^{71}$ Babül, in her research into human rights localisation among the Turkish police and judiciary during the EU accession process, explicates the complex and multi-directional nature of human rights contestation and dissemination between — and amongst - 'insider' and 'outsider' actors. She argues that (the effects of) these normative processes continue long after 'projects' and 'trainings' have been completed by local, national and 'foreign' stakeholders. ${ }^{72}$ In sum, ownership, and thus arguably the effectiveness of human rights, is increased through localisation, contestation and dissemination of the norms concerned with(in) the communities on the ground..$^{73}$ For the purposes of this chapter, these processes are summarised through the metaphor of human rights 'cross-pollinating', i.e. being contested, disseminated and vernacularised through networks that form a battleground of ideas, and 'taking root', which refers to the process of institutionalisation (both formal and social) of the norms into sustainable governance practices.

\footnotetext{
${ }^{63}$ Risse and Sikkink 1999, p. 7.

${ }^{64}$ Ibid.

${ }^{65}$ Béland and Cox 2016.

${ }^{66}$ Berman 2007; Levit 2007; Koh 2007.

${ }^{67}$ Berman 2007.

${ }^{68} \mathrm{Ibid}$.

${ }^{69} \mathrm{Ibid}$.

${ }^{70}$ Brysk 2019, p. 1.

${ }^{71}$ Merry 2006.

${ }^{72}$ Babül 2017.

${ }^{73}$ Risse and Sikkink 1999, p. 6.
} 
Local governments become important in this context with their role as the 'lowest' tier of public administration, closest to the people. ${ }^{74}$ Local governments have been enjoying widespread scholarly attention from, for example, migration studies, international relations, political science, law, sociology and geography. ${ }^{75}$ While increased urbanisation, globalisation and decentralisation caused local governments to become implicated with more human rights issues, they have also emerged as a political actor cooperating with peers and demanding more voice in national, regional and international politics, in contestation of the view of the State as monolithic. ${ }^{76}$ From Barber's 'If Mayors Ruled the World'77 to Nijman's 'Renaissance of the City', ${ }^{78}$ Aust's 'Shining Cities on the Hill', ${ }^{79}$ and Oomen and Baumgärtel's 'Frontier Cities', ${ }^{80}$ research has focussed on how local governments contribute to solutions of glocal problems such as climate change and migration management. ${ }^{81}$ Constitutional lawyers joined the discussion, exploring local governments' increasing claims for greater autonomy, powers and competences. ${ }^{82}$ For human rights localisation, cities have been described as agents (norm entrepreneurs), actors with human rights obligations, as well as arenas in which different stakeholders come together, generating localised understandings of human rights. ${ }^{83}$ In previous work I have mapped local governments' engagement with the 'formation', 'implementation', 'defence', 'coordination', 'dissemination' and 'contestation' of human rights. ${ }^{84}$

This chapter is a case study for examining these broader processes and their shortcomings. Looking at Turkish local governments and their proactive refugee policies is relevant to both formalist and sociological views on human rights effectiveness. In a formalist sense, local policy has the capacity to objectively and measurably improve the human rights realisation of refugees on the ground, reducing both the enforcement gap and the citizenship gap. From a sociological perspective, I argue that the precursor to this outcome-oriented effectiveness of human rights is the success of the underlying societal norm (that local governments ought to improve refugee rights) in influencing the behaviour of municipalities. The national reality is legal ambiguity in which it is perfectly acceptable for local governments not to engage in refugee policies. Where some local governments are proactive with regard to refugee policy, regardless of

\footnotetext{
${ }^{74}$ United Nations Human Rights Council Advisory Committee Report, The Role of Local Authorities in the Protection and Promotion of Human Rights, A/HRC/30/49, para 1.

${ }^{75}$ Sassen 2001; De Feyter et al. 2011; Barber 2014; Marx et al. 2015; Oomen et al. 2016; ZapataBarrero et al. 2017; Bendel et al. 2019; Hoffman 2019; Durmuş 2020.

${ }^{76}$ Aust 2015; Nijman 2016; Oomen and Baumgärtel 2018.

${ }^{77}$ Barber 2014.

${ }^{78}$ Nijman 2016.

${ }^{79}$ Aust 2015.

${ }^{80}$ Oomen and Baumgärtel 2018.

${ }^{81}$ See also Blank 2006.

${ }^{82} \mathrm{Hirschl}$ 2020. See also the upcoming Special Issue of the European Yearbook on Constitutional Law on local governments.

${ }^{83}$ Oomen and Durmuş 2019.

${ }^{84}$ Durmuş 2020.
} 
legal coercion, it is possible to observe the developmental stages of a societal norm, perhaps one of good-governance or human rights duties of local governments. Ideas and practices constituting this norm travel (cross-pollinate) and are institutionalised (take root) among the community of local governments, increasing the effectiveness of the norm. The four factors I will present below that facilitate/enable this 'crosspollination' and 'taking root' are grounded findings answering the question of why these processes are successful in some municipalities and not others in the Turkish context. The four factors are thus the novel, grounded theoretical contributions to the collection of theories on norms and socialisation.

Let us now briefly problematise the notion of effectiveness. In both formalist, outcome-oriented assessments of rights realisation on the ground and the socio-legal assessment of influence on behaviour of decision-makers, conclusive determination of causality between the results and human rights (as law or as social construction) is difficult. When we track the dissemination and socialisation of a norm within a community, the actors may not consider themselves to be acting under influence of that norm, and/or will be acting in the 'battleground of ideas' influenced by a myriad of them. When actors do not motivate their decisions with a direct reference to human rights, the risk of 'hineininterpretierung', or of reading human rights into motivations where they are not expressed, is high. This problem arises especially when the research participant refers to motives such as humanitarianism, non-differentialism, ethics, or morals, which are normative motivations related to human rights, but which are difficult to distinguish from each other. Regardless of our conception of effectiveness, establishing a direct link proves highly problematic. With these disclaimers, this chapter will be very modest in making statements about effectiveness. Leaving aside the challenges above for now, this chapter will consider human rights effectiveness as the cross-pollination and taking root of the norm that local governments in Turkey, despite the lack of coercive force, ought to provide services to refugees and improve their human rights realisation.

\subsection{Grounded Theory Approach and Methodology}

Grounded theory methods are 'systematic, yet flexible guidelines for collecting and analysing qualitative data to construct theories "grounded" in the data themselves' .85 The process of grounded theory involves seeking data, describing observed events, posing fundamental questions, and systematising responses thereof and other patterns emerging from data in theoretical categories. ${ }^{86}$ Data is collected until such theoretical categories are saturated, i.e. when additional data does not produce any new categories or theoretical insights on the emerging grounded theory. ${ }^{87}$ Emerging

\footnotetext{
${ }^{85}$ Charmaz 2006, p. 2.

${ }^{86}$ Ibid., p. 25.

${ }^{87}$ Ibid., p. 96.
} 
grounded theories do not exist in a theoretical vacuum, and 'refine [...], extend[...], challenge [...] or supersede [...] extant concepts. ${ }^{88}$ In reviewing literature and earlier theories, the grounded theory should be positioned in, challenge, extend and complement existing theories and their gaps. ${ }^{89}$ The proposed original concepts/theoretical categories must be explained in terms of their content, efficacy and significance. ${ }^{90}$ An emerged grounded theory that demonstrates credibility, originality, resonance and usefulness ${ }^{91}$ can not only explain and interpret a localised reality (in this case, the Turkish local governance context), but also have cross-cutting relevance for the understanding of related phenomena across disciplines. ${ }^{92}$ As Charmaz explains, 'A contextualised grounded theory can (...) end with inductive analyses that theorize connections between local worlds and larger social structures.' This is exactly what this research aims to do; to conceptualise the processes and factors that facilitate/enable local governments to go out of their way to improve the rights of refugees. A close look at these factors and processes in a high-burden, low-capacity institutional context can have cross-cutting relevance and explanatory power for how norms travel and take root in multidirectional processes within different and/or larger social and institutional contexts, starting with the local government communities of other countries with low local institutional capacity and legal autonomy.

This chapter is based on empirical field research conducted in Turkey between November 2018 and February 2019 as part of the Cities of Refuge Project. ${ }^{93}$ The research was guided by the main research question of Cities of Refuge, namely the relevance of human rights in how local governments (in Turkey, Switzerland, Italy, Greece, the Netherlands, Germany, and transnationally) receive and integrate refugees. In addition, a useful concept researched was local governments' engagement with human rights and/or refugee policy. ${ }^{94}$ The desk research consisted of analysing literature on the subject, information on the websites of municipalities and external reports on the work of municipalities for refugees. The field research included participant observation ${ }^{95}$ and nineteen interviews. These interviews were conducted with officials from eight municipalities, three city networks, three NGOs and two international organisations, and with two academics. The interviewees were selected using snowball and theoretical sampling, ${ }^{96}$ starting with local governments

\footnotetext{
${ }^{88}$ Ibid., p. 169.

${ }^{89}$ Ibid., pp. 167-169.

${ }^{90}$ Ibid.

${ }^{91}$ Ibid., pp. 182-183.

${ }^{92}$ Ibid., p. 153.

${ }^{93}$ The Cities of Refuge Project is funded by the VICI grant of the Netherlands Scientific Organisation (NWO). https://www.citiesofrefuge.eu/.

${ }^{94}$ Durmuş 2020.

${ }^{95}$ Migration and Integration Symposium, April 2018, Istanbul; International Human Rights Cities Conference, November 2018, Istanbul; Association of Municipalities, Sultanbeyli; Zeytinburnu AKDEM; Ankara Refugee Vocational Training Centre; Kecioren Migration Service Centre (OneStop-Shop).

${ }^{96}$ Charmaz 2006, p. 96.
} 
participating in the Human Rights Cities project and local governments that had received recognition in the media or among other stakeholders in the field for their proactive engagement with refugee policy. Of the selected governments, three had a proactive approach to the implementation of refugee policy, two were selected as Human Rights Cities that were not engaged in refugee policies, and three were proactively engaged in policies related to human rights in general and to refugees in particular. To protect their privacy, the names of interviewees are anonymised in this chapter. The names of municipalities are provided, unless the participants requested to remain anonymous or if anonymisation is required for safety reasons. The data collected in Turkey was analytically complemented by the author's research in the transnational field, consisting of three interviews ${ }^{97}$ and participant observation in several conferences. ${ }^{98}$ During participant observation, field notes were taken, memos were drafted as part of the reflection on findings, and the interviews were coded using NVivo. The four factors below and the concept they collectively illustrate- the crosspollination and taking root of a new norm regarding local governments and their role in realising the rights of refugees-arose as theoretical categories and concepts in this iterative process of data analysis (coding), additional data collection (theoretical sampling) and theoretical reflection.

\subsection{Factors Facilitating the Cross-Pollination and Taking Root of Human Rights as a Norm in Local Governance}

\subsubsection{Institutional Capacity in Local Governments}

Against the backdrop of a centralised governance regime and legal ambiguity, capacity is one of the most important factors indicating whether a local government is likely to engage in refugee policy. Within this framework, capacity can be defined by finances, institutional structure (i.e. departments and branches), quantity and quality of personnel, the availability of data, and the level of institutionalisation. In this context, institutionalisation represents the organisational professionalism and the capacity for-and practice of-medium and long term, systematic, accountable, assessable decision-making.

\footnotetext{
${ }^{97}$ With officials from two municipalities, Gwangju and Sao Paolo, and one official of UCLG. ${ }^{98} 2017$ Metropolis Conference, The Hague; 2018 Human Rights Cities Workshop, Graz; 2018 World Human Rights Cities Forum, Gwangju; 2018 Cities for Rights Conference, Barcelona; 2018 Fundamental Rights Forum, Vienna.
} 


\subsubsection{Budget}

The budgets of Turkish municipalities consist of income from the central government (determined on the basis of population size and an urban development score), and direct income of the local government from local taxes and its business transactions. ${ }^{99}$ While the budget of Istanbul Metropolitan Municipality competes with that of some European countries, less populated, less developed semi-urban or rural municipalities will be dealing with far smaller numbers. ${ }^{100}$ The budget calculated and assigned by the central government only takes into account the number of Turkish nationals and not the number foreigners (or refugees). ${ }^{101}$ This is a serious problem and creates inequalities between local governments and their workload, combined with the consequences of the lack of a national dispersal system allocating refugees to particular localities, disproportionate refugee populations between localities, and different levels of access to resources. One blatant example of this is Kilis, which is both a province and a municipality on the southern border of Turkey. Over the past three years, Kilis has been hosting around as many refugees as registered Turkish residents. As a result, the beneficiaries of the municipality's services have doubled while the budget has remained the same. ${ }^{102}$ Consequently, while local governments in metropolitan areas such as Ankara and Istanbul can 'afford' to create employment, education and social inclusion policies to facilitate refugee integration, municipalities such as Kilis are struggling to provide the most basic municipal services, such as clean tap water and waste and sewage management. ${ }^{103}$ Although the Turkish government has received a large sum of money under the EU-Turkey agreement, the municipalities have not received any share of those funds. Furthermore, the lack of funding dedicated to services for refugees has contributed to social tension within local communities among persons who believe that the local government are spending their 'rightful' taxpayer money on refugees. ${ }^{104}$

The problem of funding can be managed in several ways: local governments can use funding allocated in their budgets for expenditure on 'the elderly, sick and the poor' which mayors, according to the Law on Municipalities, may use at their

\footnotetext{
${ }^{99}$ Adıgüzel and Tekgöz 2019, p. 62: 'there seem to be basically two sources: (1) allocation by central government, shares from revenues of national taxes, financial assistance by central government, loans and grants and (2) taxes, fees and user charges, contributions to infrastructural investments, income from municipal assets, revenues from entrepreneurial activities, and other income. Certain criteria such as population, acreage number of villages in the city, rural population and city development index are taken into account for transferring allocation from budget to local governments'.

${ }^{100}$ Anonymous Interview \#3; Anonymous Interview \#4.

${ }^{101}$ Erdoğan 2017; Interview Sultanbeyli; Anonymous Interview \#4.

${ }^{102}$ See number of Syrian refugees under temporary protection registered by provinces at the website of the DGMM: https://www.goc.gov.tr/gecici-koruma5638; Interview TBB.

${ }^{103}$ Yaşar 2014.

${ }^{104}$ Adigüzel and Tekgöz 2019, p. 62.
} 
discretion. ${ }^{105}$ Another possibility is to continue spending from the existing municipal budget (often the budget of the social services departments) and to argue that Article 14 of the Law on Municipalities allows_-or even obliges_-local governments to include co-citizens living within their territory in their governance and service provision. ${ }^{106}$ This option may work legally, but can be problematic because of the increasing social tensions in the Turkish host community or simply by creating budget deficits. A third option that municipalities have resorted to is writing project applications to apply for funds from international organisations ('IOs') or non-governmental organisations ('NGOs'). Among the most popular partners in such projects are the EU, UNHCR, IOM, UNICEF, Save the Children, GIZ (the German Society for International Cooperation) which provide funding, a normative framework, a human rights-oriented set of goals and indicators, as well as, at times, personnel. ${ }^{107}$ This collaboration will be further developed in Sect. 6.5.3 below. A final option for local governments is cooperating with local NGOs that provide services for refugees. ${ }^{108}$ Local NGOs are observed to fill the gaps in the provision of services and the realisation of rights where local governments are unable or unwilling to serve refugees. ${ }^{109}$ However, this creates a circular effect, as we observe some local governments remain passive in the field of migration and human rights policy-making, due to a highly active civil society in their locality already providing crucial services. ${ }^{110} \mathrm{~A}$ highly creative local government, Sultanbeyli, has circumvented funding problems by setting up an NGO and applying for funding as an NGO to provide services for refugees in the locality. ${ }^{111}$ This way, Sultanbeyli can circumvent both the discomfort of foreign institutions concerning directly funding Turkish public bodies, and the discomfort of the local Turkish population in seeing their local government use municipal funds for refugees. ${ }^{112}$

\subsubsection{Personnel}

A prevalent reference in relation to capacity that emerged in the interviews was the importance of personnel. While the expertise of personnel seemed to be the most important issue for the interviewees, ${ }^{113}$ other key issues concerned the number

\footnotetext{
${ }^{105}$ Law on Municipalities, supra note 35; Erdoğan 2017, pp. 40-42.

${ }^{106}$ See Sect. 6.2 above for details.

${ }^{107}$ Interviews Anonymous \#1, Zeytinburnu, Maltepe, Sultanbeyli, Bağcılar, MBB, TBB, Keçiören, ASAM, IOM.

${ }^{108}$ Anonymous Interview \#1; Interview Keçiören; Interview ASAM.

${ }^{109}$ Field Notes \#3. Anonymous Interview \#1, Interview Keçiören, Interview ASAM.

${ }^{110}$ Interview ASAM, Interview Keçiören.

${ }^{111}$ Interview Sultanbeyli.

${ }^{112}$ Ibid.

${ }^{113}$ Interview Maltepe, Interview TBB, Anonymous Interview \#5.
} 
of personnel in relation to the workload, and problems arising from arbitrary topdown replacements and reallocations of personnel that disrupted the growth and the embedding ('taking root') of certain practices within the local government. An interview with officials from the Turkish Union of Municipalities (TBB) revealed how in a the event of a change of government following local elections, even if the new mayor had been elected from the same political party, personnel faced risks of being replaced by new staff in whom the new mayor trusted more closely, or of being relocated to a different department, outside their area of expertise. ${ }^{114}$ If the relocated or replaced official was the main (or only) person who knew 'how to get the job done' in that department, accumulated knowledge and expertise is lost. ${ }^{115}$ This phenomenon can be considered both a cause and a consequence of the lack of institutionalisation in Turkish municipalities. Because of the lack of institutionalisation, leaders can reshuffle personnel as they see fit. Simultaneously, institutionalisation is slowed down when this causes work in some departments to fall apart because the core personnel has left, especially if practices were not (yet) embedded into institutional tradition for future generations. ${ }^{116}$ On the other hand, the institutionalisation acquired by local governments often develops through years of experience in shorter projects, trainings, cooperation with external organisations, and through the dissemination of norms and practices through networks of actors in the field of local governance. ${ }^{117}$ This is in line with Babül's findings within the Turkish police and judiciary. ${ }^{118}$ These processes also depend on individual agency, as individuals from different organisations who know each other and have already worked well together successfully tend to be more inclined to work together again and thus further develop local governance expertise. ${ }^{119}$ When personnel, who had in her/his person accumulated knowledge, experience, ownership and socialisation of certain norms of good local governance, is relocated to a field outside their expertise, the chances of institutionalisation are also reduced for the local government, which could have instead benefitted from the knowledge of the individuals working for it, to embed that knowledge within institutional structures.

\subsubsection{Data}

A key element of capacity and institutionalisation in the case studies seemed to be the availability of data on the inhabitants of a specific locality. As one interviewee

\footnotetext{
${ }^{114}$ Interview TBB.

${ }^{115}$ Ibid.

${ }^{116}$ Anonymous Interview \#1, Interview Şişli, Fieldnotes \#1, example Şişli and the fate of the Department of Migration that lost its director and most of its employees.

${ }^{117}$ Anonymous Interview \#5.

${ }^{118}$ Babül 2017.

${ }^{119}$ See Chap. 8 of the present book for the relevance of Individual Agency in the introduction of human rights to local governance.
} 
put it: "You can't do anything without data." ${ }^{120}$ Data is needed for institutionalised governance, as it allows public bodies to prioritise and make decisions based on the needs of the unique composition of their constituency. Data allows for the creation of projects that meet the needs of the population. ${ }^{121}$ In addition, data is used to put together project proposals to apply for funds from international organisations and INGOs, ${ }^{122}$ and to justify municipal expenditure that is already controversial due to legal ambiguity. Data on refugees within the locality also enables coordination between different stakeholders providing financial or material aid to refugees, in order to avoid double or triple coverage, but also to ensure efficiency and to reach those most in need. ${ }^{123}$ Statistical data is mainly collected by the Turkish Statistical Institute (TUIK) in the centralised country. ${ }^{124}$ Local governments are not obliged to collect and keep data, nor is there a mainstream data collection method for local governments that want to go the extra mile. Local governments generally have information on the number of Turkish citizens registered as residents in their territory, and perhaps also on their age and gender, ${ }^{125}$ but not necessarily more.

When it comes to migrants and refugees, the situation is even more bleak. For Syrian refugees, there is no other central allocation system to determine where they will live, except for the Dublin-esque ${ }^{126}$ requirement that they reside in the provinces in which they first registered with the local offices of the DGMM. In other provinces, Syrian refugees have no access to otherwise freely available services such as health care. As such, only the Turkish police (which falls under the jurisdiction of the central government) and the DGMM have (limited) data on where Syrian refugees reside.

Turkish local governments diverge in the amount and quality of data they have, ranging from no data at all to data collected by individual social workers in the field, from data only on Turkish residents, to data only on individuals contacting the municipality with requests. While Bağcilar, Zeytinburnu, Sultanbeyli, ${ }^{127}$ and the IOM-led one-stop-shop 'Migrants' Centre' in Keçiören collected quantitative data from the individuals who contacted and requested support from the municipal facilities, Şişli collected only qualitative data through field visits. ${ }^{128}$ Although Şişli was referred to by many interviewees as an exemplary local government successful in the field human rights and migration policies, there seemed to be a lack of systematic

\footnotetext{
${ }^{120}$ Interview Sultanbeyli.

${ }^{121}$ Ibid.

${ }^{122} \mathrm{Ibid}$.

${ }^{123}$ Ibid; Interview Çankaya.

${ }^{124}$ Interviews Zeytinburnu, Maltepe.

${ }^{125}$ Interview Maltepe.

${ }^{126}$ Dublin Regulation in EU also envisages asylum seekers to be returned the first EU country of arrival. https://ec.europa.eu/home-affairs/what-we-do/policies/asylum/examination-of-applicant s_en.

${ }^{127}$ Sultanbeyli has a 'SUKOM' system in which 19.000 Syrian refugees are registered. The municipality estimates that this number is more accurate and up-to-date than those held by the central government. Interview Sultanbeyli.

${ }^{128}$ Anonymous Interview \#1.
} 
data. This appeared to be related to the lack of personnel invested in these policies (at the time of the interview), as there were initially only three, and later only one employee in the Department of Migration. Zeytinburnu supplemented the available data with large amounts of data collected through their 'Family, Women, and Disabled Centre', which also offered migrant integration services, with qualitative data from field visits.

Sultanbeyli has developed a database called 'SUKOM' as part of the Refugee Association they founded, in which the disaggregated ${ }^{129}$ data on 19.000 Syrian refugees is registered. Municipal officials estimate that this data is more accurate and up-to-date than that of the central government, as refugees are often registered in the province of their first registration, even though they have already moved to a different locality. ${ }^{130}$ With highly disaggregated data on both the composition of the local population as well as on their economic, educational, financial and social situation, Sultanbeyli was able to adapt a project initially carried out in a municipality in Germany to the local reality. Sultanbeyli looked at the number and percentage of refugees in the locality of working age who were unemployed and available to participate in training internships with local small businesses two days a week. ${ }^{131}$ One interviewee stated that 'In Turkey, not even the DGMM has a database like ours.' 132

Regardless of whether they had attempted and/or succeeded in collecting satisfactory levels of data on which to base their policy, all interviewees expressed problems and frustration about having access to data which they know are held by central government authorities such as the DGMM and the police. ${ }^{133}$ This shows how much more efficient use can be made of the time, money and efforts of public institutions, with a better appreciation for cooperation and coordination between the main actors in a given area. In Sect. 6.5.3 below, this chapter will discuss the importance of cooperation and coordination for local governments and the importance of local governments in collaborations.

\subsubsection{Project-Based Governance: An Indicator of Low Institutionalisation?}

An unexpected finding of the field research was the ubiquitous reference to the word 'project'. While Cities of Refuge colleagues who conducted research in countries such as Italy and Netherlands investigated 'policy', interviewees in Turkey repeatedly referred to 'projects' as means of local government engagement for refugees. This

\footnotetext{
${ }^{129}$ Information on the individuals includes education level, age, gender, employment status, whether they receive financial support from an institution. Interview Sultanbeyli.

${ }^{130}$ Interview Sultanbeyli.

${ }^{131} \mathrm{Ibid}$.

${ }^{132}$ Ibid.

${ }^{133}$ Interviews Zeytinburnu, Sultanbeyli, Maltepe; Anonymous Interview \#1.
} 
finding held similarities with observations from other countries, such as Greece, and was thus arguably grounded in similar reasons such as: a centralised governance regime, lack of clear competences and allocated funds for local governments in relation to migration, and the ubiquitous presence of international organisations and INGOs in the field due to these countries being considered 'frontline' or 'hot-spot' countries in terms of hosting refugees. ${ }^{134}$

Project-based governance, which appears to be very common in the Turkish context, refers to most local governments opting for short-term projects rather than long-term institutionalised policies. Most proactive municipalities develop projects themselves targeting refugees on their own and apply for external funding, or participate in projects designed by external actors such as the UNHCR, the IOM, and local and international NGOs such as Yereliz, ${ }^{135}$ the Raoul Wallenberg Institute, ${ }^{136}$ Save the Children, ${ }^{137}$ and the German Development Fund ('GIZ'). ${ }^{138}$ Closely linked to the 'Cooperation and Coordination' factor that will be discussed in the next section, many local governments both benefit from cooperation with-and are valuable partners for-other important (non-State) stakeholders in the field. Even when there is no particular framework for a 'project', a practice by local governments seeking to improve the human rights of refugees often develops spontaneously and without reference to a policy of strategic planning and budgeting. ${ }^{139}$

There are many examples of project-based governance. For instance, the Ankara Metropolitan Municipality carried out ${ }^{140}$ a project in cooperation with the UNHCR that consisted of the construction of a large facility in the outskirts of Ankara that would serve as a comprehensive vocational training centre offering integrated language courses, psychological support, and day care. ${ }^{141}$ In a collaboration between municipalities and international organisations, 'one-stop-shops' for the support of migrants were created in the municipalities of Adana, Keçiören and Şanlıurfa, together with the IOM. Run with the help of both IOM funding and personnel hired by IOM, these one-stop-shops located inside municipal facilities serve as a 'first responders' rather than a service provider for all needs. When migrants (including refugees) register with the one-stop-shop, they are guided through a registration process that collects data on their needs and wider situation. They are then forwarded to specialists in education, employment, psychological or legal support, who guide the migrant in the larger system of actors and stakeholders and assist them in resolving their problems. The project aims to serve as a learning and transition experience for local

\footnotetext{
${ }^{134}$ OECD 2018, p. 138.

${ }^{135}$ Interview Zeytinburnu, Anonymous Interview \#5.

${ }^{136}$ Interview Maltepe, Zeytinburnu; Anonymous Interview \#5.

${ }^{137}$ Interview Zeytinburnu.

${ }^{138}$ Interview Maltepe.

${ }^{139}$ Interview Zeytinburnu.

${ }^{140}$ The current situation on this project is not known, as the municipality changed (political) hands in the last local elections, and it is not known whether the previously nationalist new Mayor has permitted continuation of the project.

${ }^{141}$ Interview $\mathrm{ABB}$ and Participant Observation in the facilities.
} 
governments to adapt to providing basic human rights-related services to refugees. Sultanbeyli's 'Association for Refugees' is an NGO coordinated by the municipality's 'Strategic Planning and Project Writing' Department. Similarly, employees of Maltepe Municipality's Strategic Planning Department were also those participating in the conferences and training sessions of the pilot project 'Human Rights Cities' that the municipality was part of. Looking at municipalities such as Bağcılar, Sultanbeyli and Zeytinburnu that did have more institutionalised policies and facilities for refugees, we see a common trend; they evolved from earlier projects and enjoyed a Mayor and/or Vice Mayor, as well as other high-level municipal decisionmakers who were invested in the purpose of this project. ${ }^{142}$ Şişli, in a rare example where an entire department is dedicated to migration, did not seem to be able to conduct wide-ranging projects or programmes. This was mainly due to a lack of institutional stability (especially with frequent personnel changes due to political reasons) and a lack of support from higher-level decision-makers. That being said, even municipalities with more established services for refugees, ${ }^{143}$ such as longstanding community centres or the 'Association of Refugees', continued to implement and refer to short-term 'projects' which then might or might not be continued in a more institutionalised format. ${ }^{144}$

The appeal of projects and project-based governance is not difficult to understand. For most local governments, the provision of services to refugees only became part of the local government repertoire after the arrival of Syrian refugees in 2011. Local governments do not have as much experience in this field as they would in ensuringsay-local infrastructure and water systems are in place. Legal ambiguity, discussed in detail above, is another obstacle. As such, local government officials may not want to, and at times cannot, establish long-term policies for refugees as no budget has been allocated for this specific group in the five-year strategic plans and thus expenditure and institutionalised policies are not easily justified. Moreover, and more importantly, the regular income of local governments is calculated on the basis of number of Turkish nationals in the territory and often cannot be stretched far enough to cover the costs of social policies for refugees. Due both to such budgetary concerns and the lack of experience in this field, local governments opt for experimental projects that provide external funds and know-how from other actors in the field, but which can be discontinued when the project does not seem sustainable, appropriate or effective in the locality.

As an important side effect, interviewees from the Union of Municipalities stated that projects often facilitated sustainable learning and improved institutionalisation within local governments. One example was a project that 'taught' municipalities to collect aggregated data. ${ }^{145}$ One interviewee, who now leads a project on local governments and human rights in Turkey for an international NGO, provided an

\footnotetext{
${ }^{142}$ Interviews.

${ }^{143}$ Zeytinburnu Interview.

${ }^{144}$ Interview Bağcılar, Interview Sultanbeyli.

${ }^{145}$ Interview TBB, about the project ISKEP and its influence in the municipality of Kars, a remote, urban locality.
} 
account based on her experience working with the Union of Municipalities and a district municipality. She explained that that the EU accession process and the decentralisation (the strengthening of local governance), which accompanied a new wave of negotiations at the start of the 2000s, provided a good basis for projects and cooperation with the foreign unions of municipalities who were eager to share their know-how on local governance. ${ }^{146}$ The interviewee also explained how in the district municipality of her previous employment, a project carried out with a UN agency and local women's rights NGOs on gender mainstreaming, and the creation of gendersensitive policies measured against gender-sensitive benchmarks, was a crucial step in teaching the municipality key tools of institutionalised governance. Interviews with current staff from the same district municipality revealed that although they had no policies for refugees, they were very open to and familiar with the idea of drafting institutional human rights plans, conducting human rights-sensitive budgeting and measuring policy outcomes based on human rights indicators. ${ }^{147}$ This was closely linked to their previous experience in the field of gender equality. ${ }^{148}$ Such outcomes closely reflect Babül's findings on human rights projects funded by the EU in Turkey's police forces and judicial establishments. ${ }^{149}$ The projects described in Babül's work also improved the capacity of institutions and introduced norms, practices and standards of human rights into the normative consciousness of individuals, institutions and governance regimes. ${ }^{150}$

Interviewees also pointed out important shortcomings of project-based governance. One of the most common problems related to projects was their lack of sustainability and resilience to change in political leadership. ${ }^{151}$ The future of the IOM's three-year one-stop-shop projects became precarious in the run-up to the local elections of April 2019, as it was feared that new mayors and the newly appointed vice-mayors would shut the projects down due to mistrust, unfamiliarity, or simply lack of knowledge or shared values about its usefulness. ${ }^{152}$ Even before the local elections, however, the high-level leadership in Şanlıurfa municipality changed, causing the project with the IOM to falter and almost fail. ${ }^{153}$ Following this development, our interviewee from the Union of Municipalities reported that the IOM representatives approached the Union to seek their support and mediation in this process, and subsequently, the municipality of Şanliurfa was persuaded to continue the project. This was arguably thanks to the mediation of the Union, which was considered more as an 'insider': a 'national/local' actor. ${ }^{154}$

\footnotetext{
${ }^{146}$ Anonymous Interview \#5.

${ }^{147}$ Interview Çankaya.

${ }^{148}$ Ibid.

${ }^{149}$ Babül 2017.

${ }^{150}$ Ibid.

${ }^{151}$ Interviews TBB, Keçiören.

${ }^{152}$ Interviews TBB, IOM, Keçiören.

${ }^{153}$ Interviews TBB, IOM.

${ }^{154}$ Interview TBB.
} 


\subsubsection{Networks and the Dissemination of the Developing Norm that Local Governments Can/Should Improve Refugee Rights}

This leads us to another very important factor facilitating local governments' engagement with migration policies aimed at improving the human rights of refugees. In line with literature on how ideas travel, are contested and become norms that socialise the behaviour of members of a community, ${ }^{155}$ this section will describe the networks through which the potential new norm, namely that local governments can and ought to work for the improvement of refugee rights, is disseminated. Local governments (globally) have been characterised as part of a 'norm-generating community' developing the norms on 'human rights in the city'. ${ }^{156}$ In the Turkish context, ideas, practices and discourses on the role of local governments in improving the realisation of refugee rights have been observed to be travelling amongst actors who are institutionally placed in local governments, local NGOs, foreign NGOs, international organisations, city networks, and academics working closely with practitioners in the field. As such, norms of 'good governance' and 'human rights duties' concerning local refugee policies are contestants within the 'battleground of ideas' ${ }^{\text {'157 }}$ that Risse and Sikkink described, struggling for increased attention and ownership among members of the community of stakeholders active in migration governance. In this battleground, this new norm travels and arrives at their municipal destinations via local "pathways of influence' similar to those mapped by Brysk in the global context. ${ }^{158}$ These local 'pathways' include conferences, seminars, workshops targeting local governments, cooperation with international organisations and NGOs, the dissemination of norms through city networks, and non-institutionalised interpersonal connections. ${ }^{159}$ Individuals are crucial to these processes (see Chap. 8 of the present book on the role of 'individual agency'), including Merry's 'people in the middle', who speak both the language of the local and the transnational. ${ }^{160}$ All actors collectively participating in this processes can be considered to constitute a 'norm-generating community'. 161 This general process can be referred to, more visually, as cross-pollination.

An example of non-institutionalised cross-pollination can be found in an anecdote by an interviewee from Zeytinburnu about how the current Mayor of GaziantepFatma Şahin-once visited the community centre of Zeytinburnu in her previous role as national Minister of Family and Social Policies. ${ }^{162}$ The 'Centre for Supporting the Family, Women and the Disabled (AKDEM)' of the municipality of Zeytinburnu

\footnotetext{
${ }^{155}$ Risse and Sikkink 1999; Berman 2007; Koh 1996; Levit 2007; Brysk 2019; Durmuş 2020.

${ }^{156}$ Durmuş 2020.

${ }^{157}$ Risse and Sikkink 1999, p. 7.

${ }^{158}$ Brysk 2019.

${ }^{159}$ See again Sect. 8.5.3 of Chap. 8 in the present book.

${ }^{160}$ Merry 2006.

${ }^{161}$ Berman 2007.

${ }^{162}$ Interview Zeytinburnu.
} 
was unique in its kind at the time. ${ }^{163}$ The interviewee stated that Fatma Şahin was so impressed by the centre that in her later years as Mayor for Gaziantep, she founded the 'Gaziantep Centre for the Support of the Family (GADEM)'. The activities of these community centres in Gaziantep expanded and continued primarily through GADEM and through other similarly structured centres aimed at integrating refugee beneficiaries into municipal social services. ${ }^{164}$ The Municipality of Gaziantep went on later to become one of the most celebrated and widely publicised 'best practice' examples internationally, in the context of local refugee reception and integration. Following these developments, Fatma Şahin was invited to deliver a number of speeches at the UN in Geneva. ${ }^{165}$ Zeytinburnu's AKDEM also has a 'Department of Integration to the City', which provides guidance, registration, language courses, and mainstreamed access for refugees (including undocumented ones) to the municipality's social services provided in the AKDEM centre. ${ }^{166}$

Slightly more institutionalised pathways of cross-pollination can be city networks, projects, trainings and conferences. Conferences at the international level, such as the World Human Rights Cities Forum, and the UCLG World Congress, both enjoying wide participation from local governments around the world, can act as 'hives' for the dissemination of developing norms on 'good local governance'. ${ }^{167}$ During one of the conferences observed through participant observation in Turkey, the International Migration and Integration Symposium (April 2018), the municipalities of Bağcılar and Gaziantep extensively presented their local migration policy, accompanied by researchers, a representative of the Marmara Municipalities' Union (with a presentation of the Migration Working Group of the Union) and even the Director General for Migration Management and the Deputy Minister of Interior Affairs. Speakers shared valuable experiences, knowledge and insight into cutting-edge (local) migration policies. Among the audience were many civil servants of other local governments, such as those from Şişli, another municipality known in the field as being 'active' ${ }^{168}$ in the field of migration policy. As such, it can be said that municipalities participating in such conferences may be already invested in-and convinced by-the relevance of the newly developing norm.

However, previously convinced municipalities are not the only ones who will be exposed to such newly developing norms. Another conference that was attended, the International Human Rights Cities Conference (November 2018, Istanbul), was part of the Human Rights Cities Turkey pilot project developed by Research Worldwide Istanbul (RWI) and the Union of Municipalities of the Turkic World (TDBB)

\footnotetext{
${ }^{163}$ Interview Zeytinburnu.

${ }^{164}$ Presentation in Metropolis 2017 Conference by Sarah Kristen Biehl on her field research in Gaziantep.

${ }^{165}$ Anonymous Interview \#4. https://www.gantep.bel.tr/haber/fatma-sahin-bmde-suriyelilerin-sor unlarini-anlatti-3472.html.

${ }^{166}$ Interview Zeytinburnu.

${ }^{167}$ Durmuş 2020.

${ }^{168}$ Interview MBB; Interview Yereliz \#1; Interview Yereliz \#2.
} 
with eight municipalities of different political colours. ${ }^{169}$ Turkish and international researchers working on 'human rights in the city' were invited to speak, alongside the local NGO 'Yereliz' (translated 'We are Local'), whose objective is the 'localisation of civil society and the civilisation of local government'. ${ }^{170}$ The conference also had features of a teaching conference, given that local level human rights indicators-developed by a team of academics, the project coordinator and municipal officials - were introduced to municipalities participating in the pilot project, with the aim of receiving feedback from them. ${ }^{171}$ The collaborating academics were also recently invited by the RWI to a workshop in Graz, where the municipality of Graz (a human rights city) and experts from academia and the Swedish Association of Local Governments (SALAR) shared comprehensive information on the operationalisation of the human rights city. ${ }^{172}$ The coordinator of the Turkish human rights cities project and one of the project's Turkish academic advisors also participated and presented at the World Human Rights Cities Forum in Gwangju (2018), where they could gain deeper insights from other human rights cities such as Barcelona, Vienna, and Gwangju. ${ }^{173}$ This process demonstrates the impressively interconnected and complex nature of the dissemination of developing norms amongst actors from a variety of institutions and geographic locations. As such, the idea of the 'human rights city' can certainly be considered a 'coalition magnet' in Béland and Cox's terms, both transnationally and in the Turkish context, mobilising different stakeholders around a common ideal. ${ }^{174}$

The Human Rights Cities project in Turkey foresees all participating municipalities to adopt, through an act of their municipal legislative, a human rights city declaration in which principles such as equality and non-discrimination are recognised and committed to. ${ }^{175}$ In addition, municipalities choose priority target groups from a list of five vulnerable groups, including refugees. ${ }^{176}$ It can therefore be reasonably argued that the project was an 'arena' and a collection of processes in which the notion that refugees are legitimate beneficiaries of municipal services-just like other vulnerable right-holding group_ — and that their rights also implicate local government competences or obligations, was advocated, contested and in some cases internalised (also referred to as socialization).

\footnotetext{
${ }^{169}$ Participant Observation in the International Human Rights Cities Conference, November 2018, Istanbul.

${ }^{170}$ Yereliz Twitter Description: https://twitter.com/yerelizdernegi (own translation).

${ }^{171}$ Participant Observation in the International Human Rights Cities Conference, November 2018, Istanbul.

${ }^{172}$ Participant observation in the Workshop in Graz, March 2018.

${ }^{173}$ Participant observation in the WHRCF, October 2018.

${ }^{174}$ Béland and Cox 2016.

${ }^{175}$ Participant Observation in the International Human Rights Cities Conference, November 2018, Istanbul.

${ }^{176}$ Ibid.
} 


\subsubsection{Coordination and Cooperation Between Local Governments and Other Actors}

The third factor that emerged from the grounded data as an element facilitating the development by local governments of policies that improve the rights of refugees, was the availability and quality of cooperation and coordination with other actors. ${ }^{177}$ This element is intimately intertwined with other factors discussed above. For instance, the human rights cities project discussed earlier should also be considered as an example of cooperation. However, these two factors, while having overlapping qualities, cannot be equated with each other. While dissemination can take place in hierarchical structures and one-way interactions, cooperation requires a commitment by two of more parties to collectively seek to address common objectives and concerns.

International organisations ('IOs') such as the UNHCR and IOM have the interests of refugees in mind and seek to realise their goals through individual as well as cooperative efforts. While cooperation with central governments is important and necessary, it may not meet all the needs and objectives that these IOs have in the field. ${ }^{178}$ For instance, where national policy-making and civil servant training at the DGMM is the objective, cooperation with the central government will be crucial for an IO. ${ }^{179}$ However, for the objective of urgently improving the rights of refugees on the ground, IOs often prefer to work with local governments, as around $98.2 \%$ of Syrian refugees in Turkey reside outside reception centres in urban areas. ${ }^{180}$

Local governments also cooperate with and through regional, national and international city networks; with academics; with local and foreign NGOs (at times sharing service provision tasks or applying for funding together) and lastly with members of their local community. For example, a project jointly developed by Ankara Metropolitan Municipality and the UNHCR enabled the of a refugee vocational training centre. ${ }^{181}$ The municipality, in accordance with its role as facilitator/coordinator within their locality, ${ }^{182}$ consulted with various actors in the industrial and entrepreneurial sectors, to identify the employment needs in the locality. ${ }^{183}$ Based on this information, and with funding and the sharing of expertise by the UNHCR, the municipality identified a location for the centre, built the facilities, and started providing two stages of trainings for selected refugees who had applied to follow the certificated course. ${ }^{184}$ The first stage involves language education, and a second stage vocational training in fields where especially the industrial sectors of

\footnotetext{
${ }^{177}$ See 'Coordination of Human Rights' in Durmuş 2020.

${ }^{178}$ Thouez 2018; UNGA 2017.

${ }^{179}$ Interview IOM.

${ }^{180}$ Erdoğan 2017; Interview IOM.

${ }^{181}$ Interview ABB.

${ }^{182}$ Durmuş 2020.

${ }^{183}$ Ibid.

${ }^{184}$ Ibid. Participant observation at the facility and focus group with the employees of the facility, January 2019.
} 
Ankara needed qualified personnel. ${ }^{185}$ Having acquired commitments from companies and entrepreneurs active in Ankara on employing refugees who had received certification from the municipality, the municipality set out to train refugees (up to 600 at a time), accompanied by services that were deemed necessary in course of the project, such as free day care, psychological support, and social services. ${ }^{186}$ The facilities employ many sociologists, teachers, social workers, lawyers and translators, including those with a refugee background. ${ }^{187}$ The examples given in Sect. 6.5.1.4 above, including the 'one-stop-shops' run by IOM in cooperation with the municipalities of Keçiören, Şanlıurfa and Adana, are also illustrative of valuable access to cooperation, which can change the municipality's status on service provision with regard to refugees from non-existent to genuine commitment and experience. ${ }^{188}$

There are, of course, some risks and shortcomings. First, for many municipalities such cooperation seems not only helpful, but also essential. Budgetary constraints and legal ambiguity push local governments to cooperate with external actors through projects that are both temporary and externally funded. While such projects can play as essential role in the transfer of practical and technical knowledge as well as norms relating to the practice, ${ }^{189}$ they can also showcase a dependence of the municipality on external funding and know-how. The lacuna in capacity and institutionalisation is attempted to be filled by such cooperation. ${ }^{190}$ This is not necessarily a bleak predicament, but an unsustainable reality that legislators, human rights researchers and policymakers need to be aware of.

This leads us to the second concern that emerges from the reliance on cooperation: the inequalities in access to such cooperation. When interviewing persons in city networks, IOs and NGOs that develop and coordinate projects with local governments, it became clear that previous engagement of the local government was a factor for these individuals to be inclined to choose to contact-and work with—such local governments again. ${ }^{191}$ Such previous engagement-more specifically, proactive engagement in fields such as migration and human rights on a scale beyond the national average amongst local governments was assumed to be an indicator for likelihood of success, including sustainable results from these short-term projects that always have an explicit or implicit objective of 'capacity-building' in them. ${ }^{192}$ In one instance this issue was acknowledged and sought to be addressed. According to interviewees from the Turkish Union of Municipalities, when the IOM contacted them about the 'one-stop-shops' that they intended to develop with local governments, the Union representatives encouraged the IOM official to carry out

\footnotetext{
${ }^{185}$ Interview ABB; ibid., Participant Observation at facility and focus group with employees.

${ }^{186}$ Ibid.

${ }^{187}$ Ibid.

${ }^{188}$ Interview IOM; Interview TBB; Interview Keçiören.

${ }^{189}$ Babül 2017.

${ }^{190}$ Interview Sultanbeyli.

${ }^{191}$ Anonymous Interview \#5; Interview IOM; Interview TBB; Interview MBB.

${ }^{192}$ Anonymous Interview \#5.
} 
the project with Şanlıurfa Municipality. This was a municipality that had not previously committed itself to providing services to refugees or to other institutionalised human rights projects. However, there was a great need for such policies, dueamong others - to a large refugee population. ${ }^{193}$ The Union interviewees indicated that the IOM official was somewhat surprised by this unusual request: other candidate municipalities were all amongst those who had shown some initiative or institutional 'project experience'. ${ }^{194}$ Ultimately, however, IOM officials opted to follow this advice and carry out the project with Şanlıurfa Municipality, in addition to the Adana Metropolitan and Keçiören Municipalities. ${ }^{195}$ Interviewees from both IOM and the Union later indicated that they had experienced difficulties in the process with Şanlıurfa, stating that the context was 'very different', implying that there were cultural differences and a greater dependence on personal relationships rather than institutionalisation. ${ }^{196}$ This experience shows the validity of some of the concerns of external actors initiating projects for and with local governments.

\subsubsection{Political Will}

As a final factor, as conceptually vague as it is, political will remains an important variable. Political will does not exist in a lacuna. An actor's interests and identities, as Koh, ${ }^{197}$ Brysk, ${ }^{198}$ as well as Risse and Sikkink ${ }^{199}$ describe, are developed and constructed in a process that is strongly influenced by the above-mentioned factors of cross-pollination, in particular the dissemination of norms and cooperation with external actors. However, this section discusses 'political will', mainly as an attempt to explain why certain highly developed, institutionalised and well-connected local governments with resources will not engage in policies regarding refugees. When we look at what unites such municipalities that are otherwise very proactive (for instance, in the areas of gender equality, children's rights and the environment), we can see that there is a political concern at the leadership level that holds the personnel back from developing policies. ${ }^{200}$ This political struggle may result from the perception of the mayor and other leaders that the 'refugee issue' is the problem of Erdoğan and the AKP, and that they (who belong to the main opposition party) should not have to deal with it. ${ }^{201}$ However, this political struggle can also take place

\footnotetext{
${ }^{193}$ Interview TBB.

${ }^{194}$ Ibid.

${ }^{195}$ Interview TBB; Interview IOM.

${ }^{196}$ Interview TBB; Interview IOM; Interview Murat Erdoğan.

${ }^{197}$ Koh 1996.

${ }^{198}$ Brysk 2019.

${ }^{199}$ Risse and Sikkink 1999.

${ }^{200}$ Interview Çankaya.

${ }^{201}$ See for instance these (Turkish language) news items from the website of the municipality of İzmir including speeches of the former İzmir Mayor Aziz Kocaoğlu following visits of European
} 
between different factions within the same political party that have a power struggle over decisions and departments within the same local government. ${ }^{202}$ In one district municipality, the office working on migration was reduced to a single member of staff, with the leader of the department relocated to a different position. ${ }^{203}$ Conflicts among the current Mayor and the previous one as well as employees loyal to each of them-lead to the opening, closing and reopening of departments, to personnel being shuffled around and to the reallocation of funds. ${ }^{204}$ The Migration Department did not seem to receive consistent support or attention from the mayor(s), vice-mayors, or other strategic partners, such as colleagues from the planning and project-writing departments.

Finally, certain localities have constituencies who are particularly opposed to the presence of - and service provision - to refugees in the country, which might result in any refugee policies of that local government to be political suicide. ${ }^{205}$ In some such cases, municipalities prefer to offer urgent and essential services in secrecy. ${ }^{206}$ Some mayors and municipal governments also struggle because they have been elected within a party that is very nationalistic and whose voter-base is openly opposed to refugees. ${ }^{207}$ In such cases, even though municipalities may have humanitarian or pragmatic rationales for providing services, this will be highly risky and is better conducted in secrecy. ${ }^{208}$

\subsection{Conclusion}

Human rights have been widely criticised for their perceived lack of effectiveness. One of the most relevant of such criticisms is related to the failure of human rights to protect those who have lost the protection of their States (such as refugees). Another criticism is the worldwide disparity between the legal obligations committed to by States and the disheartening human rights violations on the ground. This chapter has discussed how research on human rights effectiveness has been shifting away from a legalist perspective foregrounding the importance of legal incorporation of international legal commitments into domestic law and an assessment of effectiveness based on formal criteria — such as treaty ratification- to more empirical, socio-legal

\footnotetext{
diplomats, indicating that he sees his role as the Mayor of İzmir (which is on the Aegean Coast, close to Greece) as assisting in holding back the refugees who want to cross to Greece. https://www. izmir.bel.tr/HaberArsivi/16084/ara/tr https://www.izmir.bel.tr/HaberDetay/17155/tr.

${ }^{202}$ Anonymous Interview \#1.

${ }^{203}$ Ibid.

${ }^{204}$ Ibid.

${ }^{205}$ Amongst these municipalities are particularly those who have been elected from the nationalist parties MHP or İyi Parti.

${ }^{206}$ Fieldnotes \#2.

${ }^{207}$ Interview Çankaya.

${ }^{208}$ Fieldnotes \#2; also see Oomen et al. forthcoming, example of Gazipaşa.
} 
assessments. This chapter advocates for this latter sociological study of the effectiveness of human rights, by following the cross-pollination and taking root of human rights, that is to say, their development, travel, contestation, and institutionalisation as norms within communities of actors. Together, the cross-pollination and taking root of human rights can bring about an ownership of human rights in communities and actors who may be-legally speaking — already bound by them. Such a study is particularly useful in contexts of low institutionalisation where legal obligations for State and sub-State actors may not be clearly fleshed out, where divisions of labour are unclear, and where human rights needs and demands on the ground are high and urgent. In such contexts, demands of international human rights law may not resonate as much as hard practical needs on the ground and the new norms (consisting of ideas, practices and discourses) claiming to address these practical realities, disseminating and diffusing within the community of actors.

This chapter presented the findings of research grounded in a context of high human rights demands on the ground, legal ambiguity for local governments on their competences and obligations concerning these demands, and insufficient and unequal levels of institutionalisation and access to external resources. Field research was conducted through interviews with, and participant observation amongst, Turkish local governments and other actors working with local governments on the development of policies that further the human rights realisation of refugees. An extreme divergence was found in how much - if at all-local governments engage with policies related to refugees. This was arguably due, at least in part, to the large discretionary space that was created by the legal ambiguity regarding their obligations and competences. Nonetheless, four factors were identified that facilitate the engagement of local governments with policies furthering the human rights of refugees: (1) the capacity and level of institutionalisation of the local government; (2) access to networks and dissemination of the norm that local governments can and ought to create policies that aim to improve the rights of refugees; (3) access to cooperation and coordination with external actors; and (4) political will. The first factors of capacity and institutionalisation included the following elements: budget, personnel, data and the prevalence of project-based governance as a sign that indicates potential shortcomings in institutionalised long-term policy development. Together, these factors illustrate the cross-pollination and taking root of human rights amongst public actors not previously familiarised with them. While factors (2) and (3) on dissemination and cooperation may focus largely on cross-pollination, factor (1) on capacity and institutionalisation corresponds to norms taking roots engrained in institutional culture and practice. Factor (4) seeks to explain external, non-generalisable factors that prevent local governments from engaging in policies that improve the rights of refugees for political reasons. 
These findings both reaffirm the important hands-on role of local governments in addressing human rights challenges on the ground, but also warn against tales of 'The $\mathrm{X}$ City ${ }^{209}$ as the ultimate all-powerful actor that is always best suited to realise and localise human rights. For local governments to reach their full potential in localising and realising human rights on the ground, they need to enjoy some basic capacities and opportunities that will allow them to become players in the field. Such basic factors may make the difference between a proactive and inactive municipality, especially in countries where local governments do not enjoy clear, well-established and wide competences and autonomy. As such, this research also encourages the scholarship on local governments and human rights to more proactively consider and study contexts in developing countries, where the needs are higher, and resources are lower than the "usual suspects" 210 of localisation literature: European and American cities. These findings are also relevant to developments at the international level regarding the documentation and codification of the formal legal role of local governments in the protection and promotion of human rights. International organisations, as well as large-scale city networks that claim democratic representation of local governments worldwide, must reach out to less privileged local governments and consider less-institutionalised contexts when making (quasi-)legal pronouncements on local governments categorically.

These findings complement previous research on how human rights crosspollinate through 'pathways of influence' ${ }^{211}$ and take root through socialisation, ${ }^{212}$ localisation ${ }^{213}$ and acculturation. ${ }^{214}$ The factors that that have emerged as theoretical categories of this grounded theorisation may be relevant and applicable to other institutional contexts (local, national and international; public or private) and processes of cross-pollination and taking root of norms therein. Recommendations for further research include normativisation ${ }^{215}$ (the development of ideas into norms) in specific contexts, with a particular focus on the delineation of the norm in the development phase. The questions 'When can a practice be understood and classified as a "human rights practice" if there is no explicit reference to human rights?' and 'What reasons behind a behaviour or practice can be considered as "human rights norms"?' were ongoing and unresolved questions in the research underlying this chapter, relating to and answerable only by tackling broader questions about the philosophical as well as empirical 'essence' of human rights.

\footnotetext{
${ }^{209} \mathrm{X}$ being an impressive, catchy adjective, see for instance 'Shining Cities on the Hill?' by Aust 2015; 'Frontier Cities' Oomen and Baumgärtel 2018; 'Accelerating Cities' Oomen et al. forthcoming.

${ }^{210}$ This is the term used in our discussions within the project Cities of Refuge, introduced in particular by my colleague Sara Miellet.

${ }^{211}$ Risse and Sikkink 1999; Brysk 2019.

${ }^{212}$ Risse and Sikkink 1999; Risse et al. 1999; Simmons 2009; Risse et al. 2013; Haglund and Stryker 2015.

${ }^{213}$ De Feyter et al. 2011; Merry 2006; Oomen et al. 2016.

${ }^{214}$ Goodman and Jinks 2004.

${ }^{215}$ Onuf 1985.
} 
If we leave aside wider questions of 'what human rights is' for the time being, the findings from Turkish local governments show that casuistic legal pronouncements on human rights law and the competences of local governments are not a sine qua non condition for local governments to engage with policies aimed at improving the human rights of refugees. This local engagement with activities in new territories set a standard and create expectations for their own future activities as well as for other local governments, effectively expanding norms on what local governments ought to do. ${ }^{216}$ One expert interviewee explained this 'development of the law on local governments' by describing that when one municipality takes a step, if there is no reaction, they continue, allowing the practice to potentially spread. ${ }^{217}$ If the Sayıstay (Court of Cassation) or other domestic courts seek to restrict or penalise them for this practice, they might fight and stand their ground legally and discursively. ${ }^{218}$ If they challenge the decision and win, or if no one opposes the new practice, this is how the law on local governments (particularly the norms on what local governments can and ought to do) is developed. ${ }^{219}$

In sum, for isolated instances of (human rights) engagement to become new norms, ideas, practices and discourses constituting the norms (such as their content, usefulness, legitimacy or necessity) have to cross-pollinate and take root. Crosspollination effectively relies on the dissemination, contestation and development of norms through institutionalised and non-institutionalised networks. Taking root will require institutionalisation both in terms of its technical elements-budget, personnel, long-term policies as opposed to short-term projects, data-and in terms of creating an institutional culture within the norm-generating community, one that socialises (new) members into accepting the norm as their own. In conclusion, for Turkish local governments, the establishment of policies that improve the human rights of refugees on the ground constitutes a norm in development. The fact that a significant proportion of interviewees indicated that they consider the local government as an actor responsible for human rights, while some interviewees do not (yet) share this opinion, supports this observation. ${ }^{220}$ It remains to be seen to what extent this norm will develop into a fully-fleshed rule in the national context, further similar norms that are proposed and in contestation in the international context, and perhaps even find its way into national and/or international law. ${ }^{221}$

\footnotetext{
${ }^{216}$ Interview Yereliz \#1.

${ }^{217}$ Ibid.

${ }^{218} \mathrm{Ibid}$.

${ }^{219} \mathrm{Ibid}$.

${ }^{220}$ Interviews Yereliz \#1, Yereliz \#2, Şişli, Anonymous \#5, MBB, TBB, Sultanbeyli, Maltepe, Zeytinburnu, Çankaya, Anonymous \#1, Keçiören, ABB.

${ }^{221}$ The international development of the norm 'human rights in the city' is described in for instance Durmuş 2020.
} 


\section{References}

Adigüzel Y, Tekgöz N (2019) Syrians in Turkey and the Role of Municipalities in Migration Management. Report by UCLG-MEWA, December 2019

An-Na'im A A (2010) Universality of Human Rights: Mediating Paradox to Enhance Practice. In: Jovanovic M, Krstic I (eds) Human Rights Today-60 Years of the Universal Declaration. Eleven International Publishing, p 29

Aust H P (2015) Shining cities on the hill? The global city, climate change, and international law. European Journal of International Law, Vol. 26, Issue 1, pp 255-278

Babül E M (2017) Bureaucratic Intimacies: Translating Human Rights in Turkey. Stanford Studies in Middle Eastern and Islamic Societies and Cultures

Barber B (2014) If Mayors Ruled the World—Rising Cities, Declining Nation States. Yale University Press

Béland D, Cox R H (2016) Ideas as coalition magnets: coalition building, policy entrepreneurs, and power relations. Journal of European Public Policy, Vol. 23, Issue 3, pp 428-445

Bendel P, Schammann H, Heimann C, Stürner J (2019) A Local Turn for European Refugee Politics Recommendations for Strengthening Municipalities and Local Communities in refugee and asylum policy of the EU. Heinrich Boll Foundation, March 2019

Berman P S (2007) A Pluralist Approach to International Law. Yale Journal of International Law $32, \mathrm{p} 301$

Blank Y (2006) Localism in the New Global Legal Order. 47 Harvard International Law Journal 263

Brysk A (2019) Introduction: contesting human rights—pathways of change. In: Brysk A, Stohl M (eds) Contesting Human Rights. Edward Elgar Publishing, Cheltenham, UK, pp. 142-158

Brysk A, Shafir G (eds) (2004) People out of Place: Globalization, Human Rights and the Citizenship Gap. Routledge

Caponio T, Borkert M (2010) The local dimension of migration policymaking. Amsterdam University Press, Amsterdam

Caponio T, Scholten P, Zapata-Barrero R (eds) (2019) The Routledge Handbook of the Governance of Migration and Diversity in Cities. Routledge, Abingdon

Charmaz K (2006) Constructing Grounded Theory: A Practical Guide Through Qualitative Analysis. SAGE

De Feyter K, Parmentier S, Timmerman C, Ulrich G (2011) The local relevance of human rights. Cambridge University Press, Cambridge

Donoho D L (2007) Human Rights Enforcement in the Twenty-First Century. 35 Ga. J. Int'l \& Comp. L. 1

Durmuş E (2020) A typology of local governments' engagement with human rights: Legal pluralist contributions to international law and human rights. Netherlands Quarterly of Human Rights, Vol. 38(1), pp 30-54

Engle K (2000) Culture and Human Rights: The Asian Values Debate in Context (1999-2000). New York University Journal of International Law and Politics

Erdoğan M M (2017) Urban Refugees-From 'Detachment' to 'Harmonisation': Syrian Refugees and Process Management of Municipalities: The Case of Istanbul, February 2017. Report conducted and published in collaboration with the Migration Policy Centre of Marmara Municipalities Union

Finnemore M (1993) International organizations as teachers of norms: The United Nations Educational, Scientific, and Cultural Organization and science policy. International Organization, Vol. 47, Issue 4, pp 565-597

Freeman M (2013) Universalism of Human Rights and Cultural Relativism. In: Sheeran S, Rodley N (eds) Routledge Handbook of International Human Rights Law. Routledge

Fraser J (2019) Challenging State-Centricity and Legalism: Promoting the Role of Social Institutions in the Domestic Implementation of International Human Rights Law. 23(6) The International Journal of Human Rights 974, p 978 
Goodhart M (ed) (2013) Human Rights-Politics and Practice, 2nd edn. OUP

Goodman R, Jinks D (2004) Socializing States: Promoting human rights through international law. Oxford University Press, Oxford

Grigolo M (2016) Towards a sociology of the human rights city: focusing on practice. In: Oomen, B, Davis MF, Grigolo M (eds) Global Urban Justice. The Rise of Human Rights Cities. Cambridge University Press, Cambridge, pp 276-293

Grigolo M (2017) Towards a Sociology of the Human Rights City-Focusing on Practice. In: Davis M, Gammeltoft-Hansen T, Hanna E (eds) Human Rights Cities and Regions. Swedish and International Perspectives. Raoul Wallenberg Institute, Malmö, pp 11-21

Hafner-Burton EM, Tsutsui K (2005) Human Rights in a Globalizing World: The Paradox of Empty Promises. 110 American Journal of Sociology 1373

Haglund L, Stryker R (eds) (2015) Closing the Rights Gap: From Human Rights to Social Transformation. University of California Press

Hathaway J, Foster M (2014) The Law of Refugee Status. Cambridge University Press, Cambridge, doi:https://doi.org/10.1017/CBO9780511998300

Hathaway O A (2005) Do Human Rights Treaties Make a Difference? Yale Law Journal, Vol. 111; Boston Univ. School of Law Working Paper No. 02-03. Available at SSRN: https://ssrn.com/abs tract $=311359$

Helfer L (2002) Overlegalizing Human Rights: International Relations Theory and the Commonwealth Caribbean Backlash Against Human Rights. 102 Colombia Law Review 1832

Hirschl R (2020) City, State: Constitutionalism and the Megacity. OUP

Hoffman S (2019) The UN Convention on the Rights of the Child, Decentralisation and Legislative Integration: A Case Study from Wales. 23(3) The International Journal of Human Rights 374, p 376

Hopgood S (2013) The Endtimes of Human Rights. Cornell University Press

Kayaoğlu A, Erdoğan M M (2019) Labor Market Activities of Syrian Refugees in Turkey, February 2019, Economic Research Forum, available at: https://erf.org.eg/publications/labor-market-act ivities-of-syrian-refugees-in-turkey/

Kennedy D (2002) The International Human Rights Movement: Part of the Problem? Harvard Human Rights Journal 15, p 101

Koh H H (1996) Transnational Legal Process. Nebraska Law Review, Vol. 71, Issue 181, 181-207

Koh H H (2007) 'Is There a "New” New Haven School of International Law?'. 32 Yale Journal of International Law 559

Korkmaz E E (2017) How do Syrian refugee workers challenge supply chain management in the Turkish garment industry? International Migration Institute Working Paper Series. Paper 133, International Migration Institute, Oxford. March 2017

Levit J K (2007) Bottom-up International Lawmaking: Reflections on the New Haven School of International Law. 32 Yale Journal of International Law 393, p 401

Marx A, Hachez N, Meuwissen K, Schmitt P, Jaraczewski J, Lewis T N, Tuovinen A K (2015) Localizing Fundamental Rights in the European Union: What is the Role of Local and Regional Authorities, and How to Strengthen It? Journal of Human Rights Practice, Vol.7, Issue 2, 246-271

Merry S E (2006) Transnational Human Rights and Local Activism: Mapping the Middle. American Anthropologist, Vol. 108, Issue 1, pp 38-51

Nijman J (2016) Renaissance of the City as a Global Actor-The Role of Foreign Policy and International Law Practices in the Construction of Cities as Global Actors. Asser Institute, Centre for International and European Law Research Paper Series, February 2016

OECD (2018) Working Together for Local Integration of Migrants and Refugees, OECD Publishing, Paris. https://doi.org/10.1787/9789264085350-en

Onuf N (1985) Do Rules Say What They Do-From Ordinary Language to International Law. 26 Harv. Int'l. L. J. 385

Oomen B, Baumgärtel M (2018) Frontier cities: The rise of local authorities as an opportunity for international human rights law. European Journal of International Law, Vol.29, Issue 2, pp $607-630$ 
Oomen B, Baumgärtel M, Miellet S, Durmuş E, Sabchev T (forthcoming) Strategies of Divergence: Local Authorities, Law and Discretionary Spaces in Migration Governance. Journal of Refugee Studies

Oomen B, Davis M F, Grigolo M (eds) (2016) Global Urban Justice: The Rise of Human Rights Cities. CUP

Oomen B, Durmuş E (2019) Cities and plural understandings of human rights: agents, actors, arenas. Journal of Legal Pluralism and Unofficial Law, Vol.51, Issue 2, pp 141-150

Posner E A (2014) The Twilight of Human Rights Law. OUP

Risse T, Ropp S C, Sikkink K (1999) The power of human rights: International norms and domestic change. Cambridge University Press, Cambridge

Risse T, Ropp S C, Sikkink K (2013) The persistent power of human rights: From commitment to compliance. Cambridge University Press, Cambridge

Risse T, Sikkink K (1999) The socialization of international human rights norms into domestic practices: Introduction. In: Risse T, Ropp SC, Sikkink K (eds) The power of human rights: International norms and domestic change. Cambridge University Press, Cambridge, pp 1-38

Sassen S (2001) The Global City, 2nd edn. Princeton University Press

Simmons B A (2009) Mobilizing for Human Rights: International Law in Domestic Politics. Cambridge University Press, Cambridge

Soohoo C, Albrisa C, Davis MF (2008) Bringing Human Rights Home: A History of Human Rights in the United States. University of Pennsylvania, Philadelphia

Taki H (2013) Effectiveness. Max Planck Encyclopedia of International Law (last updated February 2013)

Thouez C (2018) Strengthening migration governance: the UN as 'wingman'. Journal of Ethnic and Migration Studies, https://doi.org/10.1080/1369183X.2018.1441604

UNGA (United Nations General Assembly) (2017) Report of the Special Representative of the Secretary-General on Migration, 3 February 2017, U.N. Doc. A/71/728, https://undocs.org/A/ $71 / 728$

Yaşar M R (2014) Kilis'te Siginmaci Algisi: Toplumsal Otizm ve Otekilestirme Surecinin ilk Gorunumleri. Kilis 7 Aralik Universitesi Matbaasi

Zapata-Barrero R, Caponio T, Scholten P (2017) Theorizing the 'local turn' in a multi-level governance framework of analysis: A case study in immigrant policies. International Review of Administrative Studies, pp 1-6

Elif Durmuş is a Ph.D. researcher in the project 'Cities of Refuge'. She is responsible for local field research in Turkish and Swiss municipalities as well as the transnational field of cities' engagement with international (human rights) law. Following a Bachelor in Law at Ankara University (Turkey), she obtained an advanced LLM degree (cum laude) in Public International Law at Leiden University, focusing on the role of non-State actors in international law. She has been an Assistant Editor for the Leiden Journal of International Law and an Executive Editor of the Utrecht Journal of International and European Law. She is a founding editor of the blog Human Rights Here of the Netherlands Network of Human Rights Research and a part-time lecturer at University College Roosevelt, Middelburg. Her current research interests are cities' engagement with human rights, the generation, contestation and dissemination of (human rights) norms, constitutional competences of local governments around the world, and the localisation of human rights. 
Open Access This chapter is licensed under the terms of the Creative Commons Attribution 4.0 International License (http://creativecommons.org/licenses/by/4.0/), which permits use, sharing, adaptation, distribution and reproduction in any medium or format, as long as you give appropriate credit to the original author(s) and the source, provide a link to the Creative Commons licence and indicate if changes were made.

The images or other third party material in this chapter are included in the chapter's Creative Commons licence, unless indicated otherwise in a credit line to the material. If material is not included in the chapter's Creative Commons licence and your intended use is not permitted by statutory regulation or exceeds the permitted use, you will need to obtain permission directly from the copyright holder.

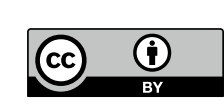

